\title{
ANALISIS PENGARUH MEKANISME GOOD CORPORATE GOVERNANCE, LEVERAGE, DAN UKURAN PERUSAHAAN TERHADAP TINDAKAN MANAJEMEN LABA PADA PERUSAHAAN MANUFAKTUR YANG TERDAFTAR DI BURSA EFEK INDONESIA TAHUN 2014-2016
}

\author{
Selviani \\ Program Studi Magister Manajemen Universitas Tarumanagara \\ selvi169@yahoo.com \\ Indra Widjaja \\ Program Studi Magister Manajemen Universitas Tarumanagara
}

Masuk : 06-12-2017, revisi : 21-12-2017 diterima untuk diterbitkan : 21-12-2017

\begin{abstract}
The purpose of this research is to test the influence of good corporate governance mechanisms, leverage, and firm size to the earnins management. This research applies good corporate governance mechanisms (with the proxy of managerial ownership, independent commissioner on the board, and audit committee), leverage, and firm size as independent variables, and earning management as dependent variable. The subject of the research is the manufacturing companies (limited to the consumer goods industry sector) which are listed in the Indonesia Stock Exchange from 2014 to 2016. The samples selection is performed by using purposive sampling method. From this method, it was collected 84 observations from 28 companies during 3 years. By using multiple regression analysis as the research method, the results shown that leverage and firm size have influenced to earning management, while good corporate governance mechanisms don't have influence to earnings management.

Keywords: Good Corporate Governance Mechanisms, Leverage, Firm Size, Earnings Management
\end{abstract}

\section{PENDAHULUAN}

Tujuan perusahaan dalam sudut pandang manajemen keuangan yaitu memaksimumkan laba dan menyejahterakan shareholder. Seiring dengan perkembangan globalisasi dan kemajuan teknologi, tujuan utama perusahaan mulai mengalami pergeseran, yang awalnya fokus pada memaksimumkan laba, secara perlahan-lahan bergeser menjadi lebih fokus pada kesejahteraan para shareholder. Adanya pergeseran tujuan utama perusahaan tersebut mengakibatkan adanya pemisahan fungsi yaitu fungsi kepemilikan dan fungsi pengelolaan, dimana pihak pemilik (principals) memberikan wewenang kepada pihak lain (agent) untuk mengurus operasional perusahaan seperti mengelola dana dan mengambil keputusan atas nama pemilik. Pemisahan fungsi tersebut dapat mendorong perbedaan kepentingan antara pihak principals dan pihak agent dan menimbulkan konflik kepentingan yang kemudian dikenal sebagai masalah keagenan (agency conflict). Hal ini dikemukakan oleh Jensen dan Meckling (1976) dalam teori keagenan (agency theory).

Dalam proses pengelolaan kegiatan operasional perusahaan, pihak manajemen (selaku agent) umumnya mengetahui informasi perusahaan lebih banyak dibandingkan para pemegang saham (selaku principals). Adanya asimetri informasi antara pihak manajemen dengan pemegang saham dan kewenangan yang dimiliki pihak manajemen tersebut dapat mendorong timbulnya perilaku menyimpang demi kepentingan pribadinya. Hal lain yang dapat memicu perilaku menyimpang tersebut yakni kesadaran pihak manajemen terkait pentingnya tingkat kinerja perusahaan. Penilaian kinerja sebuah perusahaan dapat dilihat melalui laporan keuangan. Penilaian ini dilakukan oleh para stakeholder (pihak-pihak berkepentingan) khususnya pihak eksternal perusahaan seperti kreditor dan investor. Para stakeholder 
membutuhkan informasi terkait kinerja perusahaan di masa lalu sebagai alat bantu untuk memprediksi kinerja perusahaan di masa akan datang. Berbagai upaya dilakukan pihak manajemen untuk meningkatkan kinerja perusahaan di mata para stakeholder. Pada umumnya, laba merupakan informasi penting dalam laporan keuangan dan sering digunakan sebagai dasar penilaian kinerja perusahaan sehingga pihak manajemen berupaya meningkatkan penjualan dan memperkecil biaya yang dikeluarkan guna menghasilkan laba yang besar. Untuk mencapai hal tersebut, pihak manajemen memiliki berbagai alternatif mulai dari perencanaan strategi pemasaran dan penjualan produk sampai dengan pemilihan kebijakan akuntansi dalam laporan keuangan.

Adanya perilaku menyimpang yang dilakukan pihak manajemen tersebut memberikan dampak langsung bagi pihak pemegang saham dan stakeholders. Mereka mendapatkan informasi yang tidak tepat dan akan menyebabkan kesalahan pengambilan keputusan di masa akan datang. Salah satu bentuk yang paling dikenal dari perilaku menyimpang pihak manajemen tersebut adalah praktik manajemen laba. Menurut Gumanti (2000), manajemen laba sendiri tidak harus dikaitkan dengan upaya untuk memanipulasi data atau informasi akuntansi, tetapi lebih condong dikaitkan dengan pemilihan metode akuntansi untuk mengatur keuntungan yang bisa dilakukan karena memang diperkenankan menurut accounting regulations. Lebih lanjut, disebutkan bahwa manajemen laba senantiasa dikaitkan dengan upaya untuk "mengatur" pendapatan atau keuntungan untuk kepentingan-kepentingan tertentu yang dilandasi oleh faktor-faktor ekonomi tertentu

Faktor pendorong praktik manajemen laba di suatu perusahaan dijelaskan dalam teori akuntansi positif. Teori ini meliputi tiga hipotesis yaitu hipotesis rencana bonus (bonus plan hypothesis), hipotesis hutang/ekuitas (debt/equity hypothesis), dan hipotesis cost politik (political cost hypothesis). Hipotesis rencana bonus (bonus plan hypothesis) mengungkapkan bahwa manajer perusahaan dengan rencana bonus tertentu cenderung lebih menyukai metode yang meningkatkan laba periode berjalan. Hipotesis hutang/ekuitas (debt/equity hypothesis) mengungkapkan bahwa makin tinggi rasio hutang/ekuitas perusahaan, makin besar kemungkinan bagi manajer untuk memilih metode akuntansi yang dapat menaikkan laba. Makin tinggi rasio hutang/ekuitas, makin dekat perusahaan dengan batas perjanjian/peraturan kredit. Hipotesis cost politik (political cost hypothesis) menungkapkan bahwa perusahaan yang besar cenderung memperkecil laba bersih yang dilaporkan guna menghindari kewajiban biaya yang terlalu besar.

Untuk meminimalisir praktik manajemen laba, suatu perusahaan diharapkan untuk menerapkan corporate governance yang baik. Menurut Harahap (2015), adanya pengawasan manajemen perusahaan melalui corporate governance ini diharapkan mampu membatasi ruang gerak manajemen dalam penyajian nilai laba dan mampu meminimalisir praktek manajemen laba di dalam perusahaan. Dalam penelitian ini, indikator mekanisme good corporate governance yang digunakan adalah kepemilikan manajerial, proporsi dewan komisaris independen, dan komite audit. Tujuan penelitian ini adalah untuk menguji pengaruh mekanisme good corporate governance, leverage, dan ukuran perusahaan terhadap manajemen laba. Dimana mekanisme good corporate governance mampu meminimalisir praktik manajemen laba serta leverage dan ukuran perusahaan merupakan contoh faktor pendorong tindakan manajemen laba.

\section{TINJAUAN PUSTAKA DAN PENGEMBANGAN HIPOTESIS Kepemilikan Manajerial}

Kepemilikan manajerial juga bisa dianggap sebagai cara mengurangi perilaku oportunistik manajer selaku agent. Mahiswari \& Nugroho (2014) mengungkapkan bahwa jika manajer mempunyai kepemilikan pada perusahaan maka manajer akan bertindak sesuai dengan kepentingan pemegang saham karena manajer juga mempunyai kepentingan di dalamnya. Jensen dan Meckling (1976) dalam teori keagenan menyatakan bahwa semakin besar proporsi 
kepemilikan manajerial dalam suatu perusahaan maka manajemen akan berupaya lebih giat untuk memenuhi kepentingan pemegang saham yang juga adalah dirinya sendiri. Hal ini mampu mendorong terjadinya manajemen laba.

Hasil penelitian Asward dan Lina (2015) dan Larastomo et al (2016) menunjukkan bahwa kepemilikan manajerial berpengaruh positif terhadap manajemen laba. Hasil penelitian Sriwedari (2012) dan Sari dan Asyik (2013) menunjukkan bahwa kepemilikan manajerial berpengaruh negatif terhadap manajemen laba. Hasil penelitian Mahiswari dan Nugroho (2014) menunjukkan bahwa kepemilikan manajerial tidak berpengaruh terhadap manajemen laba.

\section{H1: Kepemilikan manajerial berpengaruh terhadap tindakan manajemen laba. Proporsi Dewan Komisaris Independen}

Adanya dewan komisaris menjamin transparansi dan keinformatifan laporan keuangan sehingga memfasilitasi hak pemegang saham untuk mendapatkan informasi yang berkualitas. Dengan adanya dewan komisaris maka diharapkan dapat meningkatkan corporate governance sehingga dapat membatasi tindakan manajemen laba melalui fungsi monitoring atas pelaporan keuangan. Hanggara (2016) menyatakan bahwa dewan komisaris independen tidak berkaitan langsung dengan perusahaan yang mereka tangani. Oleh sebab itu, mereka bertugas memonitoring direksi perusahaan tanpa ada tekanan dari pihak manapun sehingga pekerjaan yang dilakukannya murni tanpa ada campur tangan dengan pihak manapun. Dengan adanya tugas monitoring dewan komisaris ini diharapkan mampu mencegah terjadinya manajemen laba.

Hasil penelitian Sriwedari (2012), Sari dan Asyik (2013), Asward dan Lina (2015), Larastomo et al (2016) menunjukkan bahwa proporsi dewan komisaris independen berpengaruh negatif terhadap manajemen laba. Hasil penelitian Nanok et al (2010) dan Mahiswari dan Nugroho (2014) menunjukkan bahwa proporsi dewan komisaris independen tidak berpengaruh terhadap manajemen laba.

\section{$\mathrm{H}_{2}$ : Proporsi dewan komisaris independen berpengaruh terhadap tindakan manajemen laba.}

Komite Audit

Komite audit adalah komite yang dibentuk oleh dewan komisaris. Komite audit diharapkan dapat membantu dewan komisaris dalam pelaksanaan tugasnya yaitu mengawasi proses pelaporan keuangan oleh manajemen. Dengan adanya pengawasan dari komite audit, maka informasi yang disajikan dalam laporan keuangan lebih informatif dan berkualitas dan mampu meminimalisir manajemen laba.

Hasil penelitian Sriwedari (2012), Sari dan Asyik (2013), Asward dan Lina (2015) menunjukkan bahwa komite audit berpengaruh positif terhadap manajemen laba. Hasil penelitian Mahiswari dan Nugroho (2014) dan Larastomo et al (2016) menunjukkan bahwa komite audit tidak berpengaruh terhadap manajemen laba.

\section{H3: Komite audit berpengaruh terhadap tindakan manajemen laba. Leverage}

Manajemen cenderung memilih metode yang mampu meningkatkan laba periode berjalan. Hal ini memungkinkan manajemen perusahaan mendapat kelonggaran dalam hal batasan kredit. Watts dan Zimmerman (1986) menyatakan bahwa jika rasio hutang perusahaan tinggi maka manajemen perusahaan cenderung memilih metode akuntansi yang mampu meningkatkan laba.

Lebih lanjut, Scoot (1997) menyatakan bahwa manajer lebih memilih metode akuntansi yang mampu meningkatkan laba saat perusahaan melanggar perjanjian kredit. Perusahaan yang memiliki rasio hutang cenderung melakukan tindakan manajemen laba guna mendapat kelonggaran dalam batasan kredit yang diterima. Hal ini dijelaskan pada hipotesis hutang/ekuitas.

Hasil penelitian Mahawyahrti dan Budiasih (2016) menunjukkan bahwa leverage berpengaruh positif terhadap manajemen laba. Hasil penelitian Sari dan Asyik (2013), 
Mahiswari dan Nugroho (2014) menunjukkan bahwa leverage berpengaruh negatif terhadap manajemen laba. Hasil penelitian Nanok et al (2010) menunjukkan bahwa leverage tidak berpengaruh terhadap manajemen laba.

\section{$\mathrm{H}_{4}$ : Leverage berpengaruh terhadap tindakan manajemen laba. Ukuran Perusahaan}

Dhaliwal et al. (1999) menyatakan bahwa perusahaan besar lebih memilih metode akuntansi yang mampu mengurangi laba bersih. Watts dan Zimmerman dalam Hery (2006) mengemukakan bahwa manajemen perusahaan besar cenderung memilih metode yang mampu menurunkan laba periode berjalan. Laba yang terlalu besar memiliki implikasi tersendiri bagi kewajiban perusahaan tersebut pada periode tersebut. Perusahaan besar dengan laba tinggi cenderung melakukan tindakan manajemen laba guna menghindari pembayaran kewajiban yang besar. Hal ini dijelaskan pada hipotesis cost politik.

Hasil penelitian Amelia dan Hernawati (2016) menunjukkan bahwa ukuran perusahaan berpengaruh terhadap manajemen laba. Hasil yang sama dikemukakan oleh penelitian Mahawyahrti dan Budiasih (2016). Hasil penelitian Mahiswari dan Nugroho (2014) menunjukkan bahwa ukuran perusahaan tidak berpengaruh terhadap manajemen laba.

\section{Hs: Ukuran perusahaan berpengaruh terhadap tindakan manajemen laba.}

\section{METODE PENELITIAN}

Populasi penelitian ini adalah perusahaan manufaktur sektor industri barang konsumsi yang terdaftar di Bursa Efek Indonesia (BEI) periode 2014 - 2016. Teknik pengambilan sampel berdasarkan purposive sampling. Adapun pertimbangan kriteria dalam pemilihan sampel penelitian: 1) Perusahaan manufaktur sektor industri barang konsumsi di Indonesia dan telah terdaftar di Bursa Efek Indonesia selama periode 2014 - 2016 secara konsisten. 2) Perusahaan yang menerbitkan laporan keuangan yang telah diaudit oleh auditor independen per tanggal 31 Desember 2014, 31 Desember 2015, dan 31 Desember 2016 dan secara konsisten dapat diakses oleh peneliti. 3) Perusahaan yang menyajikan laporan keuangannya dalam mata uang rupiah (IDR). 4) Perusahaan tidak mengalami kerugian selama periode 2014 - 2016. 5) Perusahaan memiliki informasi lengkap mengenai kepemilikan manajerial, komisaris independen, dan komite audit. Pengumpulan data tersebut dilakukan dengan cara mengunduh data laporan keuangan pada website Bursa Efek Indonesia, yaitu www.idx.co.id.

Variabel terikat dalam penelitian ini adalah manajemen laba. Manajemen laba adalah tindakan manajemen yang dapat mempengaruhi nilai laba perusahaan yang dilaporkan. Untuk pengukuran variabel ini, penelitian menggunakan Modified Jones Model dengan proksi discretionary accrual berdasar Dechow et al. (1995) dalam Mahawyahrti \& Budiasih (2016). Lebih lanjut dinyatakan bahwa model ini lebih baik dibanding model Jones standar dalam mengukur kasus manipulasi pendapatan.

TACit $=$ NIit - CFOit

Kemudian menghitung nilai total accrual (TAC) yang diestimasi dengan persamaan regresi berikut.

TACit/TAit-1 $=\alpha \mathrm{i}(1 /$ TAit-1 $)+\beta_{11} \mathrm{i}(\Delta$ REVit/TAit-1 $)+\beta_{2} \mathrm{i}($ PPEit/TAit-1 $)+\varepsilon \ldots \ldots \ldots .(2)$

Dengan menggunakan koefisien regresi diatas maka dapat dihitung nilai non discretionary accrual (NDTAC) dengan rumus berikut.

NDTACit $=\alpha \mathrm{i}(1 /$ TAit-1 $)+\beta_{1} \mathrm{i}((\Delta$ REVit- $\Delta$ RECit $) /$ TAit- 1$)+\beta_{2}$ i $($ PPEit/TAit- 1$)+\varepsilon \ldots . .(3)$

Discretionary accrual (DTA) merupakan residual yang diperoleh dari estimasi total accrual yang dihitung sebagai berikut.

DTACit $=($ TACit/TAit-1 $)-$ NDTACit

Dimana:

DTACit : Discretionary accrual perusahaan i pada periode $\mathrm{t}$

NDTACit : Non-Discretionary accrual perusahaan i pada periode $\mathrm{t}$

TACit : Total accrual perusahaan i pada periode $\mathrm{t}$ 
NIit : Net income perusahaan i pada periode $\mathrm{t}$

CFOit : Aliran arus kas operasi perusahaan i pada periode $\mathrm{t}$

TAit-1 : Total aktiva perusahaan i pada periode $\mathrm{t}-1$

$\triangle$ REVit : Perubahan penjualan perusahaan i pada periode $\mathrm{t}$

PPEit : Aktiva tetap perusahaan i pada periode $\mathrm{t}$

$\triangle$ RECit $\quad$ : Perubahan piutang perusahaan i pada periode $\mathrm{t}$

Adapun variabel bebas dari penelitian ini terdiri dari tiga indikator mekanisme good corporate governance dan dua faktor pendorong tindakan manajemen laba.

1. Kepemilikan Manajerial. Kepemilikan manajerial merupakan saham perusahaan yang dimiliki manajemen secara pribadi. Dalam penelitian Asward \& Lina (2015), kepemilikan manajerial diukur dengan variabel dummy. Apabila manajemen perusahaan tidak memiliki saham maka akan diberi angka 0. Sebaliknya, apabila manajemen perusahaan memiliki saham maka akan diberi angka 1.

2. Komisaris Independen. Dengan adanya komisaris independen, pengawasan terhadap manajemen dapat lebih efektif. Isnanta (2008) dalam Sari \& Asyik (2013) menyatakan bahwa komisaris independen diukur dengan menggunakan skala rasio melalui presentase anggota dewan komisaris yang berasal dari luar perusahaan dari seluruh ukuran anggota dewan komisaris perusahaan.

$$
\mathrm{KOMIN}=\frac{\text { Jumlah anggota komisaris dari luar perusahaan }}{\text { Total anggota dewan komisaris perusahaan }}
$$

3. Komite Audit. Asward \& Lina (2015) menyatakan bahwa komite audit dapat diukur dengan membagi jumlah anggota komite audit dengan jumlah minimum komite audit yaitu tiga orang. Berdasarkan peraturan BAPEPAM No. IX.I.5 / 2004, komite audit terdiri dari sekurang-kurangnya satu orang dewan komisaris independen dan sekurangkurangnya dua orang anggota lainnya dari luar Emiten atau Perusahaan Publik.

$$
\mathrm{KA}=\frac{\text { Jumlah Komite Audit }}{3}
$$

4. Leverage. Perubahan dalam metode akuntansi dapat mempengaruhi debt contract dan dimana perusahaan lebih banyak menggunakan perubahan metode akuntansi yang mampu meningkatkan laba. Untuk mengukur tingkat leverage dalam penelitian ini, peneliti menggunakan nilai rasio dari Rasio Utang Terhadap Ekuitas/ Debt-to-Equity Ratio (DER) yaitu jumlah dari nilai pinjaman untuk setiap investasi ekuitas (Stice et al, 2009).

$$
\mathrm{LEV}=\frac{\text { Total Kewajiban }}{\text { Ekuitas }}
$$

5. Ukuran Perusahaan. Ukuran perusahaan dapat dilihat dari seberapa besar aktiva yang dimiliki, baik aktiva lancar maupun aktiva tidak lancar. Perusahaan besar cenderung memilih metode akuntansi yang menurunkan laba. Tolak ukur dari variabel ukuran perusahaan dalam penelitian ini dilihat dari jumlah total aset perusahaan (Ln TA) pada periode bersangkutan (tahun t) (Astami et al., 2006).

$$
\text { Size }=\text { Ln Total Aset }
$$

Alat analisis yang digunakan dalam penelitian ini adalah teknik analisis regresi berganda. Model yang digunakan dalam penelitian ini adalah sebagai berikut.

Dimana:

$$
\text { DTAC }_{t}=\beta_{0}+\beta_{1} \mathrm{KM}_{t}+\beta_{2} \mathrm{KOMIN}_{\mathrm{t}}+\beta_{3} \mathrm{KA}_{\mathrm{t}}+\beta_{4} \mathrm{LEV}_{\mathrm{t}}+\beta_{5} \mathrm{SIZE}_{\mathrm{t}}+\varepsilon
$$

DTAC : Nilai Total Discretionary Accrual

KM : Kepemilikan Manajerial

KOMIN : Komisaris Independen

KA : Komite Audit 


\begin{tabular}{ll}
\hline LEV & $:$ Leverage \\
SIZE & $:$ Ukuran Perusahaan \\
$\beta_{0}$ & $:$ konstanta \\
$\beta_{1,2,3,4,5,}$ & $:$ koefisien regresi \\
$\varepsilon$ & $:$ error \\
$\mathrm{t}$ & $:$ pada tahun $\mathrm{t}$
\end{tabular}

\section{HASIL DAN PEMBAHASAN}

Selama proses pengumpulan data penelitian, diketahui jumlah populasi penelitian sebanyak 111 perusahaan selama periode pengamatan. Berdasarkan pertimbangan kriteria dalam pemilihan sampel yang telah dipaparkan sebelumnya, jumlah sampel yang memenuhi kriteria sebanyak 84 perusahaan selama periode pengamatan.

\section{Tabel 1}

Proses Seleksi Sampel Tahun 2014 - 2016

\begin{tabular}{|l|l|l|l|}
\hline Tahun yang digunakan proses seleksi sampel & 2014 & 2015 & 2016 \\
\hline Jumlah populasi yang digunakan & 37 & 37 & 37 \\
\hline Tidak sesuai kriteria karena : & & & \\
1. Data tidak tersedia di BEI & $(2)$ & $(2)$ & $(2)$ \\
2. Perusahaan yang mengalami kerugian & $(7)$ & $(7)$ & $(7)$ \\
\hline Jumlah sampel yang digunakan & 28 & 28 & 28 \\
\hline
\end{tabular}

\section{Tabel 2}

\section{Hasil Uji Koefisien Determinasi}

\begin{tabular}{|l|l|l|l|l|}
\hline Model & R & R Square & Adjusted R Square & Std. Error of the Estimate \\
\hline 1 & $.417^{\mathrm{a}}$ & .174 & .121 & $4.3 \mathrm{E}-14$ \\
\hline
\end{tabular}

Berdasarkan hasil uji koefisien determinasi, diketahui nilai adjusted $\mathrm{R}^{2}$ adalah sebesar 0.121 atau $12.1 \%$ berarti $12.4 \%$ variasi variabel manajemen laba dapat dijelaskan oleh variasi dari kelima variabel independen dalam model regresi ini yaitu kepemilikan manajerial, komisaris independen, komite audit, leverage, dan ukuran perusahaan. Sisanya sebesar $87.9 \%$ dijelaskan oleh sebab-sebab lain (variabel lainnya) diluar model penelitian ini. Nilai R sebesar 0.417 menunjukkan nilai koefisien regresi berganda yang berarti bahwa hubungan antara variabel independen (kepemilikan manajerial, komisaris independen, komite audit, leverage, dan ukuran perusahaan) dengan variabel dependen (manajamen laba) adalah positif dan cukup.

Tabel 3

\section{Hasil Uji Statistik F}

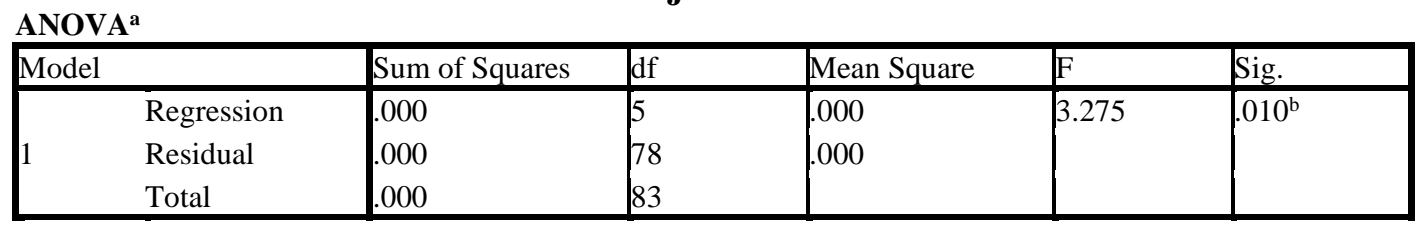

a. Dependent Variable: DTACit

b. Predictors: (Constant), SIZE, KM, LEV, KA, KOMIN

Tingkat signifikan dalam penelitian ini adalah sebesar 5\%. Hasil uji statistik F menunjukkan nilai F hitung sebesar 3.275 dengan nilai Sig. 0.010 dapat disimpulkan bahwa kelima variabel independen yaitu kepemilikan manajerial, komisaris independen, komite audit, leverage, dan komite audit secara bersama-sama (simultan) berpengaruh signifikan terhadap variabel dependen yaitu manajemen laba pada model regresi penelitian ini. 
Tabel 4

Hasil Uji Regresi Berganda

\begin{tabular}{|l|l|l|l|l|l|}
\hline \multirow{2}{*}{ Model } & \multicolumn{2}{|l|}{ Unstandardized Coefficients } & $\begin{array}{l}\text { Standardized } \\
\text { Coefficients }\end{array}$ & T & Sig. \\
\cline { 2 - 5 } & B & Std. Error & Beta & \\
\hline (Constant) & $2.307 \mathrm{E}-013$ & .000 & & 2.661 & .009 \\
KM & $4.630 \mathrm{E}-015$ & .000 & .050 & .470 & .640 \\
KOMIN & $-2.146 \mathrm{E}-014$ & .000 & -.073 & -.639 & .525 \\
KA & $1.070 \mathrm{E}-014$ & .000 & .053 & .494 & .623 \\
LEV & $2.889 \mathrm{E}-014$ & .000 & .365 & 3.342 & .001 \\
SIZE & $-7.784 \mathrm{E}-015$ & .000 & -.270 & -2.445 & .017 \\
\hline
\end{tabular}

Berdasarkan hasil uji regresi berganda, variabel independen kepemilikan manajerial memiliki nilai Sig. sebesar 0.640 dan nilai t sebesar 0.470. Nilai tersebut jauh di atas tingkat signifikan yang ditetapkan 5\% (0.05). Jadi, dapat disimpulkan bahwa kepemilikan manajerial tidak berpengaruh terhadap tindakan manajemen laba. Hasil pengujian menunjukkan bahwa penelitian tidak dapat menolak $\mathrm{H}_{0}$. Hasil penelitian ini sesuai dengan penelitian Mahiswari dan Nugroho (2014) bahwa kepemilikan manajerial tidak berpengaruh terhadap manajemen laba. Hal ini menunjukkan bahwa adanya kepemilikan saham oleh pihak manajerial khususnya pada perusahaan manufaktur sektor industri barang konsumsi di Indonesia tidak mendorong manajemen untuk melakukan tindakan manajemen laba guna memenuhi kepentingan pemegang saham (termasuk kepentingan dirinya sendiri).

Variabel independen komisaris independen memiliki nilai Sig. sebesar 0.525 dan nilai t sebesar - 0.639. Nilai tersebut jauh di atas tingkat signifikan yang ditetapkan 5\% (0.05). Jadi, dapat disimpulkan bahwa komisaris independen tidak berpengaruh terhadap tindakan manajemen laba. Hasil pengujian menunjukkan bahwa penelitian tidak dapat menolak $\mathrm{H}_{0}$. Hasil penelitian ini sesuai dengan penelitian Soenarno, Natasha, dan Widadi (2010), Mahiswari dan Nugroho (2014), serta Amelia dan Hernawati (2016) bahwa komisaris independen tidak berpengaruh terhadap manajemen laba. Hal ini menunjukkan bahwa jumlah komisaris independen yang tinggi tidak dapat membatasi terjadinya tindakan manajemen laba di perusahaan khususnya pada perusahaan manufaktur sektor industri barang konsumsi di Indonesia.

Variabel independen komite audit memiliki nilai Sig. sebesar 0.623 dan nilai t sebesar 0.494. Nilai tersebut jauh di atas tingkat signifikan yang ditetapkan 5\% (0.05). Jadi, dapat disimpulkan bahwa komite audit tidak berpengaruh terhadap tindakan manajemen laba. Hasil pengujian menunjukkan bahwa penelitian tidak dapat menolak $\mathrm{H}_{0}$. Hasil penelitian ini sesuai dengan penelitian Mahiswari dan Nugroho (2014) dan Larastamo et al (2016) bahwa komite audit tidak berpengaruh terhadap manajemen laba. Hal ini menunjukkan bahwa jumlah komite audit tidak dapat membatasi terjadinya tindakan manajemen laba di perusahaan khususnya pada perusahaan manufaktur sektor industri barang konsumsi di Indonesia.

Variabel independen leverage memiliki nilai Sig. sebesar 0.001 dan nilai t sebesar 3.342. Nilai tersebut jauh di bawah tingkat signifikan yang ditetapkan 5\% (0.05). Jadi, dapat disimpulkan bahwa leverage berpengaruh positif terhadap tindakan manajemen laba. Hasil pengujian menunjukkan bahwa penelitian ini berhasil menolak $\mathrm{H}_{0}$. Hasil penelitian ini sesuai dengan penelitian Sari dan Asyik (2013), Mahiswari dan Nugroho (2014), serta Mahawyahrti dan Budiasih (2016) bahwa leverage berpengaruh terhadap manajemen laba. Hal ini menunjukkan bahwa adanya kecenderungan pihak manajemen khususnya pada perusahaan manufaktur sektor industri barang konsumsi di Indonesia untuk memilih metode akuntansi yang mampu meningkatkan laba demi mendapatkan kelonggaran dalam hal batasan kredit. Hasil ini sesuai dengan pendapat Watts dan Zimmerma (1996) dan Scoot (1997).

Variabel independen ukuran perusahaan memiliki nilai Sig. sebesar 0.017 dan nilai t sebesar - 2.445. Nilai tersebut jauh di bawah tingkat signifikan yang ditetapkan 5\% (0.05). Jadi, dapat disimpulkan bahwa ukuran perusahaan berpengaruh negatif secara signifikan 
terhadap manajemen laba. Hasil pengujian menunjukkan bahwa penelitian ini berhasil menolak $\mathrm{H}_{0}$. Hasil penelitian ini sesuai dengan penelitian Amelia dan Hernawati (2016) dan Mahawyahrti dan Budiasih (2016) bahwa ukuran perusahaan berpengaruh terhadap manajemen laba. Hal ini menunjukkan bahwa semakin besar ukuran perusahaan khususnya pada perusahaan manufaktur sektor industri barang konsumsi di Indonesia maka pihak manajemen perusahaan cenderung memilih metode akuntansi yang mampu menurunkan laba periode berjalan demi mengurangi besarnya jumlah kewajiban perusahaan pada periode tersebut. Hasil ini sesuai dengan pendapat Watts dan Zimmerma (1996) dan Scoot (1997).

\section{KESIMPULAN DAN SARAN}

Kesimpulan yang diperoleh dari penelitian ini adalah sebagai berikut: 1) Kepemilikan majerial tidak berpengaruh terhadap tindakan manajemen laba. 2) Proporsi dewan komisaris independen tidak berpengaruh terhadap tindakan manajemen laba. 3) Komite audit tidak berpengaruh terhadap tindakan manajemen laba. 4) Leverage berpengaruh positif terhadap tindakan manajemen laba. 5) Ukuran perusahaan berpengaruh negatif terhadap tindakan manajemen laba. 6) Pengaruh variabel mekanisme good corporate governance (dengan proksi: kepemilikan manajerial, komisaris independen, dan komite audit), leverage, dan ukuran perusahaan terhadap tindakan manajemen laba adalah sebesar $12.1 \%$ dan sisanya $87.9 \%$ tindakan manajemen laba dipengaruhi oleh variabel lain di luar model penelitian ini.

Berdasarkan hasil penelitian dan kesimpulan diatas, maka peneliti mengajukan beberapa saran terkait penelitian ini adalah sebagai berikut: 1) Pengambilan objek penelitian diharapkan tidak hanya satu sektor industri pada perusahaan manufaktur saja, tapi seluruh sektor industri perusahaan manufaktur atau bidang perusahaan lainnya sehingga hasil penelitian lebih mampu mempresentasikan seluruh perusahaan yang terdaftar di Bursa Efek Indonesia. 2) Periode pengamatan penelitian diharapkan lebih panjang sehingga jumlah sampel penelitian lebih banyak dan memungkinkan memperoleh kondisi yang sebenarnya pada penelitian tersebut. 3) Pemilihan variabel bebas lainnya yang mampu mempengaruhi manajemen laba seperti kepemilikan institusional (sebagai proksi mekanisme good corporate governance) dan tingkat profitabilitas. 4) Pemilihan alat ukur lain atas manajemen laba yaitu dengan pendekatan conditional revenue model yang dikembangkan oleh Stubben (tidak menggunakan proksi discretionary accrual - modified jones model).

\section{REFERENSI}

Amelia, W. \& Hernawati, E. (2016). Pengaruh komisaris independen, ukuran perusahaan dan profitabilitas terhadap manajemen laba. $\mathrm{NeO} \neg$ Bis, 10(1), 62-77.

Astami, E.W., Hartadi, B., \& Tower, G. (2006). Factors explaining management preferences of accounting for goodwill prior to the implementation of IFRS 3: A cross-country study. Gadjah Mada International Journal of Business, 8(1), 43-67.

Asward, I. \& Lina. (2015). Pengaruh mekanisme corporate governance terhadap manajemen laba dengan pendekatan conditional revenue model. Jurnal Manajemen Teknologi, 14(1), $15-34$.

Ghozali, I. (2006). Aplikasi analisis multivariate dengan program SPSS. Semarang: Badan Penerbit Universitas Diponegoro.

Ghozali, I. \& Chariri, A. (2007). Teori Akuntansi (edisi 3). Semarang: Badan Penerbit Universitas Diponegoro.

Gumanti, T. A. (2000). Earnings management: Suatu telaah pustaka. Jurnal Akuntansi Keuangan, 2(2), 104-115.

Hamdani. (2016). Good Corporate Governance Tinjauan Etika dalam Praktik Bisnis. Jakarta: Penerbit Mitra Wacana Media. 
Hanggara, K. (2016). Pengaruh corporate governance terhadap manajemen laba (Studi empiris pada perusahaan manufaktur yang terdaftar di Bursa Efek Indonesia pada tahun 20102012). Jakarta: Pascasarjana Magister Manajemen Universitas Tarumanagara.

Harahap, S. S. (2015). Teori Akuntansi (edisi revisi 2011). Jakarta: Rajawali Pers.

Hery. (2006). Teori akuntansi positif: Rekayasa dan perataan laba. Perpustakaan Unika Atma Jaya, 11(2), 285-296.

Komite Nasional Kebijakan Governance. (2006). Pedoman Umum Good Corporate Governance Indonesia. Retrieved November 17, 2016, from ECGI Website http://www.ecgi.org/codes/documents/indonesia_cg_2006_id.pdf

Larastomo, Juoro, Perdana, Halim Dedy, Triatmoko, Hanung, Sudaryono, \& Eko Arief. (2016). Pengaruh tata kelola perusahaan dan penghindaran pajak terhadap manajemen laba pada perusahaan manufaktur di indonesia. Esensi: Jurnal Bisnis dan Manajemen, 6(1), 63-74.

Mahawyahrti, P. T. \& Budiasih, I G. A. N. (2016). Asimetri informasi, leverage, dan ukuran perusahaan pada manajemen laba. Jurnal Ilmiah Akuntansi dan Bisnis, 11(2), 99-109.

Mahiswari, R. \& Nugroho, P. I. (2014). Pengaruh mekanisme corporate governance, ukuran perusahaan dan leverage terhadap manajemen laba dan kinerja keuangan. Jurnal Ekonomi dan Bisnis, 18(1), 1-20.

Margaretha, F. \& Asmariani, A. (2009). Faktor-faktor agency theory yang mempengaruhi hutang. Media Riset Bisnis \& Manajemen, 9(1), 1-20.

Peraturan Menteri Negara Badan Usaha Milik Negara, No. PER - 01/MBU/2011 (2011).

Priyastama, R. (2017). Buku Sakti Kuasai SPSS. Yogyakarta: Start Up.

Ratnaa, D. (2014). Makalah Industri Manufaktur dan Ketenagakerjaan. Retrieved November 13, 2016, from http://agentofcentaurus.blogspot.co.id/2014/01/makalah-industrimanufaktur-dan.html.

Sari, S. R. \& Asyik, N. F. (2013). Pengaruh leverage dan mekanisme good corporate governance terhadap manajemen laba. Jurnal Ilmu \& Riset Akuntansi, 2(6), 1-21.

Soenarno, Y. N., Natasya, \& Widadi, B. A. (2010). Faktor-faktor yang mempengaruhi manajemen laba perusahaan publik di Indonesia pada tahun 2008. Journal of Applied Finance and Accounting, 3(1), 60-74.

Sriwedari, T. (2012). Mekanisme good corporate governance, manajemen laba dan kinerja keuangan perusahaan manufaktur di Bursa Efek Indonesia. Jurnal Mediasi, 4(1), 78-88.

Suharli, M. (2005). Teori akuntansi positif: Studi lanjutan perkembangan teori akuntansi. BALANCE, 2(1), 72-84.

Widarjono, A. (2007). Ekonometrika: Teori dan Aplikasi untuk Ekonomi dan Bisnis, (edisi kedua). Yogyakarta: Ekonisia FE Universitas Islam Indonesia. 